\title{
ДОСЛІДЖЕННЯ АЛГОРИТМІВ ІДЕНТИФІКАЦЇ̈ ПАРАМЕТРІВ МОДЕЛІ В АДАПТИВНІЙ СИСТЕМІ КЕРУВАННЯ ЕКСТРУДЕРОМ
}

\begin{abstract}
Вступ
Екструзійні методи формування виробів в екструдерах грунтуються на пластикації матеріалу, тобто переведенні його у в'язкотекучий стан, та продавлюванні розплаву через формувальний пристрій - екструзійну головку. Екструзійним методом виготовляють труби, плівки, листи, профільні вироби, наносять ізоляцію на кабелі тощо. [1]

Така різноманітність процесів зумовлює використання екструдерів на різних стадіях у технологічних схемах виробництв полімерів і виробів з них, переробки біосировини, вторинної сировини та інших матеріалів. [1]

Із літератури відомо [2], що ефективність роботи екструдера визначаеться його тепловим режимом. Тому основними керувальними змінними екструдера $є$ температури, значення яких $є$ функцією продольної та радиальної координат. Необхідний температурний режим по зонах екструдера підтримуеться за допомогою спеціальних нагрівачів, які встановлюються на зовнішній поверхні апарату.

Таким чином, для виробництва високоякісної продукції потрібно створити ефективну систему керування тепловим режимом цього процесу.
\end{abstract}

\section{Постановка задачі}

Під час процесу екструзії в апараті відбувається інтенсивна деформація матеріалу та зростання тиску. Також відбуваються процеси: нагрівання матеріалу за рахунок енергії дисипації та енергії, що підводиться від системи нагрівання циліндра; ініційовані зростаючою температурою та тиском хімічні, фразові та інші перетворення; змішування компонентів. Така різноманітність процесів обумовлюе нестаціонарні властивості екструдера як об'екта керування, а також некеровану зміну режимів його роботи, що можна класифікувати як неконтрольовані випадкові збурення.

Система керування, що створюеться, повинна також враховувати те, що зміна режиму нагрівання хоча б однієї з зон викликає зміни температур інших зон, що в свою чергу важко врахувати за допомогою одноконтурних систем керування окремих температурних зон, які реалізуються на базі релейних або ПІД-регуляторів.

Принцип адаптації застосовують у тих випадках, коли складність керованого процесу (нестаціонарного об'єкта) досягає такого рівня, при якому вплив неповноти апріорної інформації про умови роботи системи стае істотним і неможливо забезпечити задану якість процесів керування

(c) П.І. Бідюк, О.А. Жученко , 2010 
без пристосування системи до змінних непередбачуваним чином умов фрункціонування. [3]

У зв'язку з цим для підвищення якості керування екструдером вбачаеться за доцільне застосувати адаптивну багатоконтурну систему керування. Ефективність адаптивної системи керування багато в чому залежить від методів ідентифікації параметрів моделі, що використовуються.

Таким чином, задачею даної роботи було дослідити різні алгоритми ідентифікації параметрів математичної моделі процесу екструзії з точки зору ефективності їх застосування в адаптивній системі керування ним.

\section{Адаптивна система керування процесом екструзії}

У даній роботі як об’ект дослідження розглядався екструдер зовнішнім діаметром $0,24 \mathrm{~m}$, а довжиною $2,4 \mathrm{~m}$, на якому встановлені 4 нагрівачі потужністю 0,6 кВт кожний.

У зв'язку з цим екструдер розглядався як багатовимірний об'єкт керування, який має 4 входи (потужності нагрівачів) та 4 виходи (температура в екструдері кожної зони)

Як відомо [4], адаптивна система керування складається з таких основних блоків (рис. 1): оцінки параметрів моделі, розрахунку параметрів системи та розрахунку керувань.

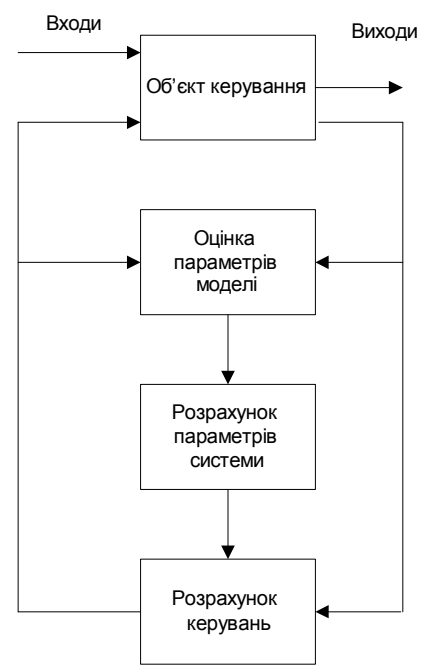

Рис. 1 - Структурна схема адаптивної системи керування екструдером

У даному дослідженні як об'єкт керування використовувалась така математична модель.[5]

$$
\frac{1}{\alpha} \frac{\partial T(r, z, t)}{\partial t}=\frac{1}{r} \frac{\partial T(r, z, t)}{\partial r}+\frac{\partial^{2} T(r, z, t)}{\partial r^{2}}+\frac{\partial^{2} T(r, z, t)}{\partial z^{2}}
$$


де $T(r, z, t)$ - температура циліндру екструдера;

$\alpha$ - тепловий коефіцієнт;

$r$ - поточне значення радіальної координати циліндру, $r_{1} \leq r \leq r_{2}$;

$z$ - осьова відстань, $0 \leq z \leq L$;

$L$ - довжина циліндру; $t-$ час.

У якості математичної моделі, параметри якої потрібно адаптувати, використана модель авторегресії - ковзного середнього (АРКС) [6]

$$
A(d) y(t)=B(d) u(t)
$$

де

$u(t), y(t)-m$-розмірні вектори керування та виходів (температур) відповідно в момент часу $t$, $A(d), B(d)$ - поліноміальні матриці розмірністю $m \times m$.

$$
\begin{aligned}
& A(d)=1+A_{1} d+A_{2} d^{2}+\ldots+A_{n a} d^{n a} \\
& B(d)=B_{k} d^{k}+B_{k+1} d^{k+1}+\ldots+B_{n b} d^{n b} \\
& k \geqslant 1
\end{aligned}
$$

$d$ - оператор зсуву назад;

$k$ - запізнювання в каналі керування; $t=0,1,2, \ldots$ - дискретна змінна часу.

Як критерій оптимальності в адаптивній системі керування був використаний такий критерій:

$$
J=1 / 2\left\{\|y(t+k)-w(t)\|_{Q}^{2}+\|W(d) u(t)\|^{2}\right\}
$$

Математичну модель (2) перепишемо у вигляді:

$$
y(t+k)=A(d) y(t)+B(d) u(t)
$$

Продиференціюємо це рівняння по $\mathrm{u}(\mathrm{t})$ з врахуванням (3). Отримаємо такий результат:

$$
\partial J / \partial u(t)=B_{0}^{T} Q[A y(t)+B u(t)-w(t)]+W_{0}^{T} W(d) u(t)
$$

Прирівнюючи це рівняння до нуля, маємо наступний вигляд закону керування:

$$
\left[B_{0}^{T} Q B(d)+W_{0}^{T} W(d)\right] u(t)=-B_{0}^{T} Q A(d) y(t)+B_{0}^{T} Q w(t)
$$

\section{Алгоритми ідентифікації параметрів математичної моделі}

Математична модель авторегресії - ковзного середнього (АРКС) (4) може бути представлена у вигляді [4]

$$
y(t)=\phi^{T}(t-1) \theta(t)
$$

У даній роботі для визначення змінного вектора параметрів $\theta(t)$ досліджувались такі алгоритми ідентифікації [3]. 
Алгоритм A:

$$
\begin{aligned}
& \Theta(t)=\Theta(t-1)+\frac{P(t-1) \varphi(t-1) \varepsilon^{T}(t)}{1+\varphi^{T}(t-1) P(t-1) \varphi(t-1)} \\
& \left.\varepsilon^{(} t\right)=y^{T}(t)-\varphi^{T}(t-1) \Theta(t-1) \\
& P(t)=P(t-1)+\frac{P(t-1) \varphi(t-1) \varphi^{T}(t-1) P(t-1)}{1+\varphi^{T}(t-1) P(t-1) \varphi(t-1)}
\end{aligned}
$$

Алгоритм Б:

$$
\begin{gathered}
\Theta(t)=\Theta(t-1)+\frac{\gamma \varphi(t-1) \varepsilon^{T}(t)}{1+\varphi^{T}(t-1)-\varphi(t-1)} \\
\varepsilon(t)=y(t)-\Theta^{T}(t-1) \varphi(t-1)
\end{gathered}
$$

Ефективність того чи іншого алгоритму ідентифікації визначалась за здатністю системи керування забезпечити заданий температурний режим екструдера, включаючи пусковий період його експлуатації та враховуючи можливі зміни температурного режиму у подальшому.

\section{Імітаційне моделювання}

Результати проведеного дослідження представлені на рис. 2-7.

Суть даного дослідження полягала у наступному. На першому етапі досліджувалась ефективність даної адаптивної системи під час розігріву екструдера від температури $20{ }^{\circ} \mathrm{C}$ до заданої. Екструдер був умовно розділений на 4 зони (по кількості використаних нагрівачів). Завдання по температурам для кожної зони відповідно: перша $-60{ }^{\circ} \mathrm{C}$, друга -80 ${ }^{\circ} \mathrm{C}$, третя $-100{ }^{\circ} \mathrm{C}$, четверта $120^{\circ} \mathrm{C}$.

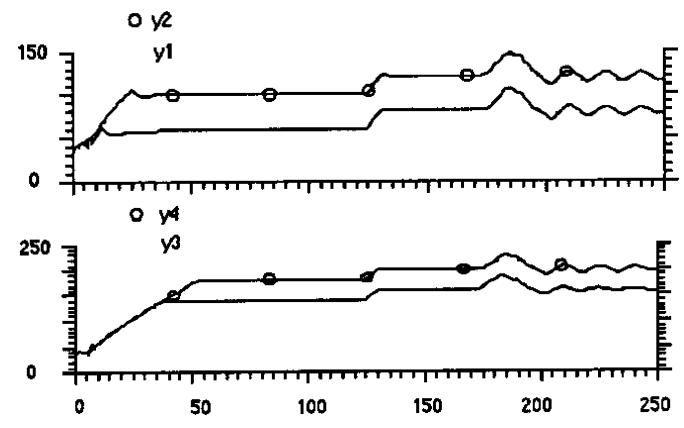

Рис. 2 - Температура по зонах (у1-у4), використовуючи алгоритм А

Як видно з рисунку 2, система з алгоритмом А успішно справляеться із задачею, хоча мають місце суттеві коливання керувань по зонах (рис. 3,4 ). Адаптивна система з алгоритмом Б характеризуеться значно меньшими коливаннями керувань. 

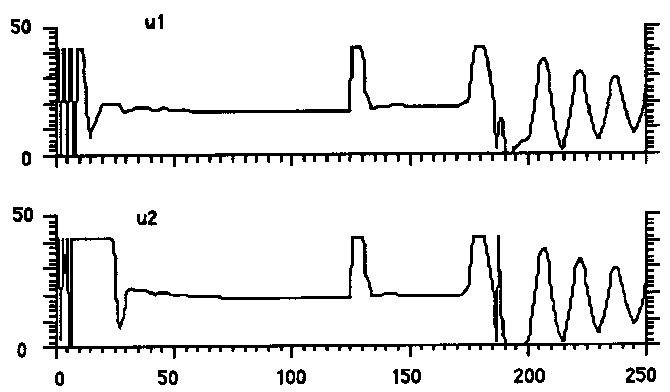

Рис. 3 - Керувальні сигнали (u1,u2) з використанням алгоритму А
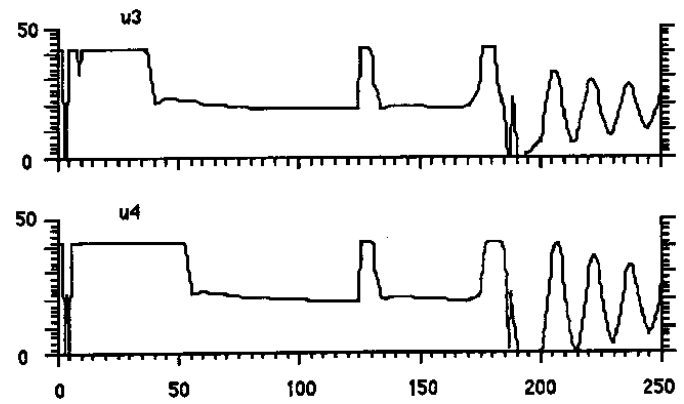

Рис. 4 - Керувальні сигнали $(\mathrm{u} 3, \mathrm{u} 4)$ з використанням алгоритму А

На другому етапі дослідження у момент часу $t=125$ хвилин було внесено детерміноване збурення: температури зон було одночасно збільшено на $20{ }^{\circ} \mathrm{C}$. Як видно з представлених результатів (рис. 2-5) фрактично всі алгоритми ідентифікації, що розглядалися, виявилися достатньо ефективними.

На третьому етапі дослідження у момент часу $t=175$ хвилин було введено збурення синусоїдального характеру. При таких умовах адаптивна система ефективно працюе тільки з алгоритмом Б. При цьому такі збурення на роботу екструдера практично не впливають. Застосування інших алгоритмів призводить до коливного режиму роботи екструдера як по температурам, так і по керуванням.

\section{Висновки}

Результати проведеного дослідження засвідчили, що використання принципу адаптації при побудові системи керування температурним режимом процеса екструзії може забезпечити високу ефективність роботи технологічного обладнання, що при цьому використовується.

У даній роботі досліджено два алгоритми ідентифікації параметрів математичної моделі процесу і вибраний найбільш ефективний. Показа- 
$\circ y$

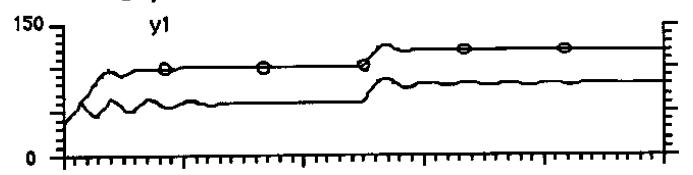

0 y

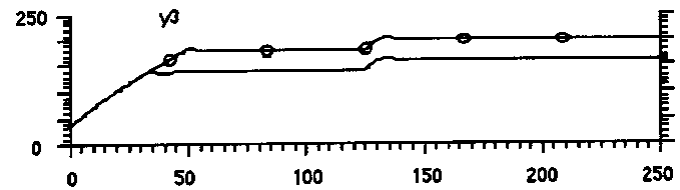

Рис. 5 - Температура по зонах (у1-у4), використовуючи алгоритм Б
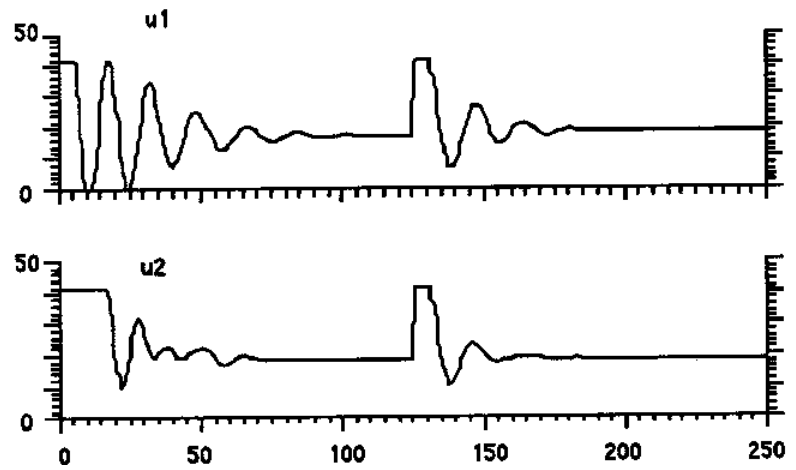

Рис. 6 - Керувальні сигнали $(\mathrm{u} 1, \mathrm{u} 2)$ з використанням алгоритму Б
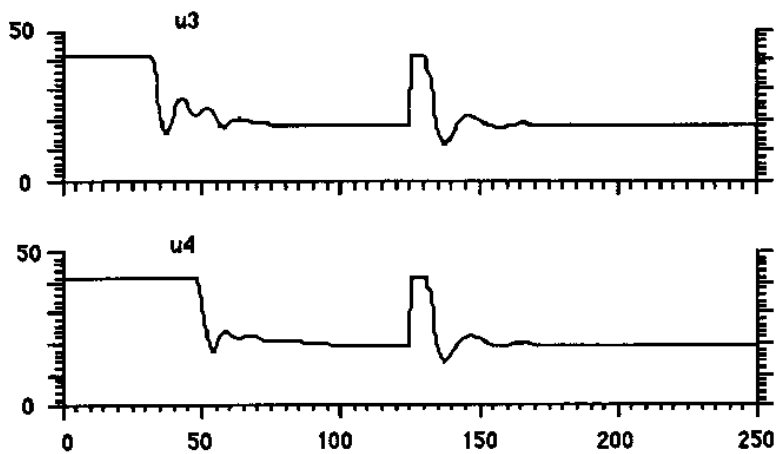

Рис. 7 - Керувальні сигнали $(\mathrm{u} 3, \mathrm{u} 4)$ з використанням алгоритму Б но, що адаптивна система працює якісно при дії збурень різного характеpy. 
У подальших дослідженнях доцільно розглянути й інші алгоритми ідентифікації, які можуть бути використані в адаптивній системі керування екструдером, а також дослідити якість керування такої системи при дії випадкових збурень довільного характеру.

\section{Література}

1. Ким В.С. Теория и практика экструзии полимеров. КОЛОСС, 2005. $568 \mathrm{c}$.

2. Мак-Келви Д. Переработка полимеров. М.:Химия, 1965. - 442с.

3. Эйкхофрф П. Основы идентификации систем управления. М., 1975. $683 \mathrm{c}$.

4. Методы робастного, нейро-нечеткого и адаптивного управления: Учебник / Под ред. Н.Д. Егупова. М.: Изд-во МГТУ им. Н.Э. Баумана, 2002. $-744 \mathrm{c}$.

5. Митрошин В.Н. Диссертация доктора технических наук "Математическое моделирование и автоматическое управление объектами с распределенными параметрами в технологических процессах изолирования кабелей связи", Самара, 2006. - 236с.

6. Антонов В.Н., Терехов В.А., Тюкин И.Ю. Адаптивное управление в технических системах. СПб.: С.-Петербургского университета, 2001. $-244 \mathrm{c}$.

Отримано $12.03 .2010 \mathrm{p}$. 